\title{
Cultura e Política no Brasil: balanço de uma década (2011-2020)
}

\author{
Daniela Vieira dos Santos \\ Mário Augusto Medeiros da Silva \\ Sandra Assunção
}

O dossiê Cultura e Política no Brasil: balanço de uma década (2011-2020) inspira-se no conhecido ensaio do sociólogo e crítico literário brasileiro Roberto Schwarz, "Cultura e Política, 1964-1969" publicado em sua forma final em O pai de família e outros estudos. Alguns dos artigos aqui presentes também se relacionam a um dos argumentos do autor sobre aquele período: após o golpe de estado civil-militar de 1964, apesar da vitória política de uma ditadura reacionária e de direita, setores culturais mantiveram "relativa hegemonia cultural" progressista, alinhados às esquerdas políticas. Tal hegemonia, ainda que relativa, expressou-se pelos movimentos artísticos na literatura, teatro, artes plásticas, música, arquitetura, publicações, cinema e manifestações de rua em grandes centros urbanos, bem como nos meios rurais, em razão de movimentos de alfabetização camponesa e organização de lutas pela terra. Seriam anos em que o país se mostrava "irreconhecivelmente inteligente", argumento do ensaio. Numa avaliação posterior e um tanto mais desalentada, na "Nota, 1978" antecedendo o texto, Schwarz afirmaria que poderia ter errado em sua avaliação. Mas algo havia acontecido com o Brasil e "o tempo passou e não passou".

Não obstante, a sociedade brasileira passou por mudanças sociais nas décadas seguintes, contraditoriamente de maneira conservadora e progressista, regredindo e avançando na pauta dos direitos modernos (políticos, civis e sociais) reafirmada pela agenda dos direitos humanos no pós 2a Guerra Mundial. Igualmente, apesar de tudo, há o movimento das forças sociais em condições adversas para ideias progressistas: esta lição explicitada no ensaio de Schwarz serve para pensarmos a referida década (2011-2020) selecionada para este dossiê, pois ela é um marco entre épocas distintas. Da Constituição de 1988, adjetivada como "Cidadã", às primeiras eleições livres, da sequência de alternância democrática por meio do processo eleitoral (Fernando Collor e Itamar Franco, Fernando Henrique Cardoso, Lula) para, finalmente, os 
governos democraticamente eleitos de Dilma Rousseff (2010-2014) e sua destituição. Embora o segundo mandato de Rousseff tenha sido interrompido sem a apresentação de um claro e legal crime de responsabilidade praticado, há uma sociedade em movimento, com sujeitos sociais regredindo e avançando em algo nada estabilizado que se pode chamar de democracia brasileira.

Esta segunda década do século XXI se iniciou sob turbulências depois de um período irreconhecível e aparentemente inédito em estabilidade da experiência política republicana no Brasil. Figuram aí as manifestações de 2013, o impeachment de 2016, o governo de transição de Michel Temer (2017) e a eleição de Jair Bolsonaro, ao final de 2018. Desde 2017, especialmente a partir de $1^{\circ}$. de janeiro de 2019, os trilhos da democracia se apresentam de forma vertiginosa, assustadora e perigosamente regressiva para a agenda dos direitos modernos.

A cultura tem estado no centro do debate político com a ascensão da extremadireita no Brasil contemporâneo, sendo a tentativa de controlá-la um dos pilares da política governamental. A eleição de Jair Bolsonaro veio acompanhada e permanece conectada a invectivas constantes contra o chamado "marxismo cultural", à "ideologia de gênero", ao "vitimismo" racial e ao "globalismo" diplomático nas mais variadas esferas, tornando-se flagrante o flerte com o retorno à censura e ao autoritarismo no cinema, na música, no teatro, na educação, nas políticas direcionadas a negros, indígenas, população LGBTQI+, pessoas com deficiência, mulheres etc.

O controle da cultura e o conservadorismo nos costumes constitui-se força motriz desde $1^{\circ}$ de janeiro de 2019, expressos pela extinção do Ministério da Cultura e seu rebaixamento retrógrado a uma secretaria, pela subordinação das políticas de direitos civis de mulheres e negros a um Ministério da Família, e por uma política diplomática na Chancelaria do Itamaraty que contraria diferentes aspectos das últimas décadas de atuação do Ministério das Relações Exteriores. Tudo isso em conjunto com os discursos de dirigentes da Secretaria de Cultura e da Fundação Palmares que explicitam racismo, discriminação e autoritarismo públicos, tendo como resultados práticos, por exemplo, o descaso com patrimônios como o da Cinemateca Brasileira (parcialmente incendiada em julho de 2021) ou da Fundação Palmares, alvo de censura aos livros da instituição. Os tempos vividos são ainda mais 
tenebrosos, agravados pela pandemia da SARS COVID 19 e por uma gestão necropolítica e negacionista da saúde pública no Brasil, totalizando 600 mil mortos no país em setembro de 2021.

A despeito disso, a sociedade brasileira se move. E de forma "imprevisível, dormita a História", como também escreveu Schwarz em "As ideias fora do lugar", publicado em Ao vencedor, as batatas. Tudo permanece, destarte, em aberto, num cenário contemporâneo tão cerrado para o horizonte imediato, sobre o qual se deve refletir.

Portanto, num chamado à reflexão e também na perspectiva de que este balanço da década sirva de documento a um processo ainda em curso, os artigos que compõem este dossiê investigam aspectos das mudanças sociais e a ação de alguns dos e das protagonistas que compõem a sociedade brasileira. São temas em debate a ascensão de movimentos conservadores, de extrema direita, com hegemonia temporária por meio da vitória eleitoral de 2018; a expressão do controle de favelas cariocas e as percepções de seus moradores; a agenda política da classe média e seus sentidos pouco progressistas; a cena literária por meio dos saraus e slams, com suas visões sobre as turbulências políticas; projetos artísticos que respondem, a contrapelo, à pauta conservadora e regressiva com relação a negros, indígenas, pobres, mulheres e população LGBTQI+. Além disso, ao final dessa década que coincide com o início da pandemia do Covid 19, projetos inovadores de documentação e sobrevivência científica e cidadã são também apresentados, num contexto tão pouco coletivista e anticientífico como tem sido tratada a crise sanitária mundial em nosso país.

As distintas formas pelas quais esses anos vertiginosos foram plasmados nas manifestações artísticas também contemplam o presente dossiê. Na seção Varia, o leitor encontrará algumas dessas expressões por meio de obras de artistas brasileiros contemporâneos, cuja provocação, revolta e inquietude com o tempo presente formalizam as suas distintas produções. Nos referimos à poesia de Dinha (Maria Nilda de Carvalho Mota), aos escritos de Guiomar de Grammont, Monique Lima e Milton Hatoum, às ilustrações e quadrinhos de Marcelo D'Salete e João Pinheiro e à resenha do filme dirigido por Filipe Galvon, Encantado, o Brasil em Desencanto (2018) escrita por Mélanie Toulhoat. 
A literatura, os quadrinhos, o teatro e o cinema se debruçaram sobre narrativas mal contadas/escamoteadas à espera de bons narradores. Alguns estão aqui. Em tempos tão sombrios não emudeceram diante do impensável que assola o país: produziram relatos de sobrevivência nas periferias urbanas, em meio à crise sanitária e política, à violência crônica e opressão; narrativas que surgem no bojo de uma luta por justiça e trabalho de memória, profetizando, a contragosto, a ascensão de uma extrema direita ao poder; homenagem prestada aos artistas engajados que a pandemia levou; análise do processo de encantamento e desencanto político no país na última década e, consequentemente, do surgimento de movimentos sociais e políticos conservadores.

Uma vez que o mundo da cultura é marcado por conflitos e contradições que perpassam a vida política brasileira, esperamos que os artigos deste dossiê inspirem não somente a leitura, mas que contribuam ao debate político em aberto sobre como chegamos até aqui e, mais urgente, como sairemos dessa condição desalentadora. Porém, não esperamos o retorno à "normalidade". Conforme disse Ailton Krenak recentemente, "Tomara que não voltemos à normalidade, pois, se voltarmos, é porque não valeu nada a morte de milhares de pessoas no mundo inteiro". 